\title{
Rosemary extract and celery-based products used as natural quality enhancers for colonial type salami with different ripening times
}

\author{
Extrato de alecrim e produtos derivados do aipo como agentes naturais potencializadores da qualidade \\ de salames coloniais com diferentes tempos de maturação
}

\author{
Teresinha Marisa BERTOL ${ }^{1 *}$, Angela Maria FIORENTINI², Maria José Honorato dos SANTOS 3 , \\ Maristela Cortez SAWITZKI ${ }^{4}$, Vicky Lilge KAWSKI ${ }^{1}$, Ingrid Beatriz Lermen AGNES ${ }^{5}$, \\ Camila Dalla COSTA ${ }^{5}$, Arlei COLDEBELLA ${ }^{1}$, Letícia dos Santos LOPES ${ }^{1}$
}

\begin{abstract}
This study aimed to evaluate the use of rosemary (Rosmarinus officinalis) extract (RE), celery (Apium graveolis), and low levels of $\mathrm{NO}_{3}$ and $\mathrm{NO}_{2}$ as natural agents to enhance the quality of colonial salami. Salami was produced according to three treatments: (A) Control: 0.1\% curing salt; (B) Rosemary: $0.05 \%$ curing salt $+0.5 \%$ RE (rosemary extract); and (C) Rosemary+celery: $0.14 \%$ Veg $503+0.27 \%$ Veg 504 (sea salt plus celery) $+0.5 \%$ of $\mathrm{RE}$ (rosemary extract). There was no effect $(\mathrm{P}>0.05)$ of the treatments on water activity, Na content, and residual $\mathrm{NO}_{3}$ and $\mathrm{NO}_{2}$. Fatty acids $\mathrm{C} 18: 2$ and $\mathrm{C} 20: 4$ were reduced $(\mathrm{P}<0.05)$ during the ripening period in the Control treatment indicating possible oxidation. The use of celery resulted in lower $\mathrm{pH}$ values $(\mathrm{P}<0.05)$ in the salami. Reduced addition of $\mathrm{NO}_{3}$ and $\mathrm{NO}_{2}$ resulted in salami lighter in color (higher $\mathrm{L}^{*}$ values, $\mathrm{P}<0.05$ ) at the $12^{\text {th }}$ day of ripening. In conclusion, celery-based products proved to be an effective source of $\mathrm{NO}_{2}$ and $\mathrm{NO}_{3}$ for color development, but the low $\mathrm{pH}$ of the product indicates the need for better evaluation of its use in fermented salami. The $\mathrm{RE}$ (rosemary extract) reduced fat oxidation in salami, but this needs further evaluation.

Keywords: natural preservatives; colonial type meat products; vegetable extracts.
\end{abstract}

\section{Resumo}

Objetivou-se avaliar o efeito do extrato de alecrim (EA; Rosmarinus officinalis) e do aipo (Apium graveolis) e de baixos níveis de adição de $\mathrm{NO}_{3}$ e $\mathrm{NO}_{2}$, como agentes naturais potencializadores da qualidade dos salames coloniais. Foram produzidos salames de acordo com três tratamentos: (A) Controle: 0,1\% de sal de cura; (B) Alecrim: 0,05\% de sal de cura + 0,5\% de EA; (C) Alecrim+aipo: 0,14\% de Veg 503 + 0,27\% de Veg 504 (sal marinho e aipo) + 0,5\% de EA. Não houve efeito ( $\mathrm{p}>0,05)$ dos tratamentos sobre o conteúdo de Na, atividade de água e $\mathrm{NO}_{3}$ e $\mathrm{NO}_{2}$ residuais. Houve redução $(\mathrm{p}<0,05)$ dos ácidos graxos C18:2 e C20:4 durante o período de maturação no tratamento Controle, indicando sua possível oxidação. $\mathrm{O}$ uso do aipo resultou em baixo $(\mathrm{p}<0,05) \mathrm{pH}$ no salame. A redução da adição de $\mathrm{NO}_{3}$ e $\mathrm{NO}_{2}$ resultou em salames com coloração mais clara (valores de $\mathrm{L}^{\star}$ mais elevados, $\mathrm{p}<0,05$ ) aos 12 dias de maturação. Conclui-se que o aipo foi efetivo como fonte de $\mathrm{NO}_{3}$ e $\mathrm{NO}_{2}$ para desenvolvimento da cor, mas o baixo $\mathrm{pH}$ do produto indica a necessidade de melhor avaliar sua utilização em salames fermentados. Os salames produzidos com EA poderão apresentar diferencial de qualidade pela menor oxidação das gorduras, mas isto necessita ser confirmado em estudo futuros.

Palavras-chave: conservantes naturais; embutidos coloniais; extratos vegetais.

\section{Introduction}

Homemade products derived from pork, such as salami, are traditionally consumed by members of family farming systems in Southern Brazil and are popularly known as homemade rural products. In addition to the homemade system, the colonial type salami is also produced by small agribusiness. In the context of agro-industrialization, for both, family farming systems and small or large agribusiness, the tendency is to continually add value to these products considering that pig farming and pork processing are a source of income for social and economic development in Southern Brazil (ESPÍNDOLA, 2002).
An alternative to add value to the colonial type salami is to reduce the use of chemical additives while maintaining safety and the quality of the product with regard to the microbiological, sensory, and physicochemical aspects. The replacement of chemical additives such as antioxidants (2-t-butyl-4-methoxyphenol, BHA, and 2,6-di-t-butyl-4methylphenol, BHT, etc.), color enhancers, and control agents of undesirable microorganism/pathogen (containing nitrite and/or nitrate curing salt) with natural products is a promising alternative.

${ }^{1}$ Embrapa Suínos e Aves, BR 153, Km 110, Vila Tamanduá, CEP 89700-000, Concórdia, SC, Brasil, e-mail: tbertol@cnpsa.embrapa.br

2 Universidade Federal de Pelotas - UFPEL, Campus Universitário de Capão do Leão, CP 354, CEP 96010-900, Pelotas, RS, Brasil

${ }_{3}^{3}$ Associação de Pequenos Agricultores do Oeste Catarinense - APACO, CEP 89802-056, Chapecó, SC, Brasil

${ }^{4}$ Universidade Federal do Pampa - UNIPAMPA, Campus Uruguaiana, BR 472, Km 592, CEP 97500-970, Uruguaiana, RS, Brasil

${ }^{5}$ Universidade do Contestado - UNC, Campus Concórdia, Rua Vitor Sopelsa, 3000, Bairro Salete, CEP 89700-000, Concórdia, SC, Brasil

${ }^{*}$ Corresponding author 
A total of $30 \%$ fat is added to the original composition of salami, which is susceptible to rancidity and oxidation.

The compounds resulting from fat deterioration can compromise product quality resulting in unpleasant odor, discoloration and dehydration, and potential risk to human health due to the production of toxic or toxigenic substances (MORRISSEY et al., 1998). Therefore, antioxidants are used in order to promote product quality to control free radicals and oxidation of fats and other compounds of meat mixture. Regarding the control of pathogenic microorganism, the Brazilian legislation (BRASIL, 2000) requires the addition of curing salt (sodium or potassium nitrate and nitrite) in the formulation of raw meat products. Another important function of curing salts is the development of red color, characteristic of fermented raw meat products.

Some plant extracts have been evaluated for their properties as natural antioxidants (YEN; CHEN, 1995; LOPEZBOTE et al., 1998; LEE; SHIBAMOTO, 2002; BASMACIOGLU; TOKUSOGLU; ERGUL, 2004; RABABAH et al., 2004), which is mainly attributed to the flavonoids present in the plants. Some extracts were classified by Lee and Shibamoto (2002) according to their antioxidant power in the following order: thyme (Thymus vulgaris) > basil (Ocimum basilicum L.) > rosemary (Rosmarinus officinalis) > chamomile (Matricaria recutita) $>$ lavender (Lavandula spp.) > cinnamon (Cinnamomum zeylanicum).

The antibacterial and antioxidant effect of rosemary, evaluated in vitro, was investigated by Asolini, Tedesco and Carpes (2006) and Klancnik, Guzej, and Kolar (2009), who observed that the result was dependent on the concentration of solute and solvent used. Its antioxidant effect on meat products was investigated by Basmacioglu, Tokusoglu and Ergul (2004) and Riznar et al. (2006). Although the antioxidant properties of various plants and herbs have been studied in vitro and in foodstuffs, there are no reports of studies on salami.

Celery (Apium graveola) is a leafy plant with significant levels of nitrites and nitrates (SANTAMARIA, 2006); it is a possible natural source of these compounds for use in cured/ fermented products. Its effects in cooked and cured products were studied by Sindelar et al. (2007a, b), who demonstrated the potential for such use although additional studies are needed.

Currently, rosemary oil extract and celery-based products are commercially available for use as food additives, thus allowing their regular use in the manufacture of processed products. Considering that these additives are natural extracts, this study evaluated the effect of rosemary oil extract, celerybased products, and low levels of added sodium nitrate and nitrite on the microbiological and physicochemical characteristics and on the oxidation of salami, characterized as colonial type salami.

\section{Material and methods}

\subsection{Salami preparation}

The pork meat cuts for salami production were obtained from animals from the Embrapa Swine and Poultry (Concórdia, Santa Catarina State, Brazil), slaughtered at an abattoir with municipal sanitary inspection. The pork used was composed of $60 \%$ ham, $30 \%$ shoulder, and $10 \%$ back-fat, all ground uniform in size. Deboning of carcasses was performed 24 hours after slaughter, and the meat was frozen for 48 hours. After this period, meat and fat were ground, and the ingredients were added according to three treatments: (A) Control: Addition of $0.1 \%$ curing salt; (B) Rosemary: Addition of $0.05 \%$ curing salt $+0.5 \%$ deodorized rosemary oil extract; and $(C)$ Rosemary + celery: Addition of $0.14 \%$ Veg $503+0.27 \%$ Veg 504 from the compound celery powder and sea salt $+0.5 \%$ deodorized rosemary oil extract. The formulation used in each treatment is shown in Table 1 . The mixture remained at rest under refrigeration $\left(0-4{ }^{\circ} \mathrm{C}\right)$ for 2 hours. The sausages were manufactured at the Federal Institute of Education, Science and Technology of Santa Catarina - Campus Concórdia, Concórdia, Santa Catarina State. Four replicates (batches) were performed for each treatment.

A portion of approximately $350 \mathrm{~g}$ of the mixture was stuffed into synthetic cellulose casings ( $55 \mathrm{~mm}$ diameter), smoked at $25{ }^{\circ} \mathrm{C}$ for 8 hours, and ripened under controlled humidity for 12 days. Afterwards, the salami was stored under room temperature and humidity until the end of the sampling period (30 days).

At $0,6,12,18,24$, and 30 days of ripening, the salami samples were randomly gathered for microbiological, physicochemical and fatty acids analyses. All tests were performed in replicate.

The extract of rosemary and Veg stable compounds (503 and 504), both formulated with dehydrated celery and sea salt, were purchased from commercial companies.

\subsection{Microbiological analyses}

Microbiological analyses of salami were performed on samples collected at $0,6,12$, and 30 days of ripening, according

Table 1. Formulation used in the preparation of salami in each treatment.

\begin{tabular}{|c|c|c|c|}
\hline \multirow{3}{*}{$\begin{array}{c}\text { Raw material } \\
\%\end{array}$} & \multicolumn{3}{|c|}{ Treatment } \\
\hline & (A) & (B) & (C) \\
\hline & Control & Rosemary & Rosemary + Celery \\
\hline Pork $^{\mathrm{a}}$ & 95.77 & 95.27 & 94.91 \\
\hline Salt $(\mathrm{NaCl})$ & 2.91 & 2.96 & 2.96 \\
\hline Curing salt ${ }^{\mathrm{b}}$ & 0.1 & 0.05 & - \\
\hline Celery powder Veg $503^{c}$ & - & - & 0.14 \\
\hline Celery powder Veg $504^{\mathrm{d}}$ & - & - & 0.27 \\
\hline Nutmeg & 0.03 & 0.03 & 0.03 \\
\hline Black pepper powder & 0.2 & 0.2 & 0.2 \\
\hline Wine & 0.26 & 0.26 & 0.26 \\
\hline Garlic & 0.2 & 0.2 & 0.2 \\
\hline Rosemary extract ${ }^{\mathrm{e}}$ & - & 0.5 & 0.5 \\
\hline Sugar & 0.5 & 0.5 & 0.5 \\
\hline Starter culture $\mathrm{f}^{\mathrm{f}}$ & 0.025 & 0.025 & 0.025 \\
\hline \multicolumn{4}{|c|}{ 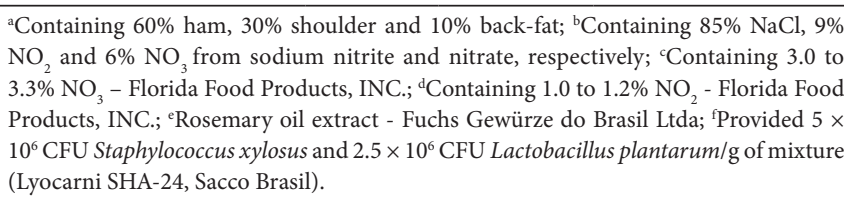 } \\
\hline
\end{tabular}


to APHA (AMERICAN..., 1992). The analyses consisted of the estimated count of the population of lactic acid bacteria, Gram-positive cocci, and catalase-positive, as well as detection of spoilage and pathogenic microorganisms.

Twenty-five grams of each sample were added to $225 \mathrm{~mL}$ of sterile $0.1 \%$ peptone water (w/v) (Oxoid) and homogenized in a stomacher (ITR, model MK 1204) for 2 minutes. Subsequent decimal dilutions were prepared using the same diluent, and the sample with appropriate dilution was inoculated into selective medium and incubated under specific conditions: De Man, Rogosa and Sharp Agar - MRS (Oxoid) for lactic acid bacteria $\left(30{ }^{\circ} \mathrm{C} / 72\right.$ hours), the plates were placed in an anaerobic jar (Anaerojar Assembly - CODE AG25 - Oxoid) with $\mathrm{CO}_{2}$ enriched air (AN Anaerogen $2.5 \mathrm{~L}$ - Oxoid); Brain Heart Infusion Agar - BHI (Oxoid) for Staphylococcaceae ( $35^{\circ} \mathrm{C} / 48$ hours); Plate Count Agar - PCA (Oxoid) for total aerobic mesophilic bacteria $\left(30{ }^{\circ} \mathrm{C} / 72\right.$ hours); Brilliant Green Bile (2\%) broth - BGBB (Oxoid) for total coliforms (method NMP at $37^{\circ} \mathrm{C} / 48$ hours); EC broth (Oxoid) for thermotolerant coliforms (MPN method at $42{ }^{\circ} \mathrm{C} / 24$ hours); Baird-Parker Agar (Oxoid), plus egg and tellurite emulsion (Oxoid) for Staphylococci coagulase - positive (at $37^{\circ} \mathrm{C} / 48$ hours); and Perfringens Agar Base - TSC (Oxoid).

For the detection of Salmonella ssp, pre-enrichment was performed by suspending $25 \mathrm{~g}$ in $225 \mathrm{~mL}$ of BPW (1\%) (w/v) (Merck) and incubating at $37^{\circ} \mathrm{C} / 16$ hours Selective enrichment was performed by transferring $0.1 \mathrm{~mL}$ pre-enriched medium to $10 \mathrm{~mL}$ of Rappaport-Vassiliadis (Merck) and to $10 \mathrm{~mL}$ of Selenite Cystine broth (Oxoid), respectively. Next, all tubes were incubated at $42{ }^{\circ} \mathrm{C} / 24$ hours. After incubation, each selective broth was streaked onto enriched modified BPLS agar (Merck) and XLD agar (Merck), and all plates were incubated at $37^{\circ} \mathrm{C}$ for 18-24 hours.

For detection of Listeria spp, selective enrichment was performed by adding $25 \mathrm{~g}$ of sample to $225 \mathrm{~mL}$ of Listeria selective enrichment broth (Merck) and incubating at $30{ }^{\circ} \mathrm{C} / 24$ hours. For a secondary enrichment, $0.1 \mathrm{~mL}$ preenrichment broth was transferred to Fraser broth (Merck) and incubated at $35{ }^{\circ} \mathrm{C}$ for 48 hours. Then, a loop full of enriched culture was streaked onto PALCAM agar (Merck) and incubated at $30{ }^{\circ} \mathrm{C} / 48$ hours and on Oxford agar (OA) and incubated at $360{ }^{\circ} \mathrm{C} / 24$ hours.

The results were expressed as colony forming units per gram of sample (CFU. $\mathrm{g}^{-1}$ ) or most probable number per gram of sample (MPN.g $\left.{ }^{-1}\right)$.

\subsection{Physicochemical and color analyses}

Water activity, $\mathrm{NO}_{2}$, and $\mathrm{NO}_{3}$ were analyzed at $0,6,24$, and 30 days of ripening. Na content was analyzed on the $12^{\text {th }}$ and $30^{\text {th }}$ days of ripening, while the $\mathrm{pH}$ was measured at $0,6,12$, 18,24 , and 30 days. Color measurements $\left(\mathrm{L}^{*}, \mathrm{a}^{*}\right.$, and $\left.\mathrm{b}^{*}\right)$ were carried out at $12,18,24$, and 30 days of ripening.

Sodium was analyzed in the dry sample according to the methodology of AOAC (ASSOCIATION..., 1995). The sample was digested with a mix of nitric and perchloric concentrated acids, at high temperature $\left(210^{\circ} \mathrm{C}\right)$. Sodium reading was taken on a flame photometer.

The $\mathrm{pH}$ was measured according to AOAC(ASSOCIATION..., 1995). Water activity (Aw) was determined using a digital Testo 400 CE device (Testo GmbH \& Co., Brazil).

The CIE Lab $\left(\mathrm{L}^{*}, \mathrm{a}^{*}, \mathrm{~b}^{*}\right)$ system was used for color measurements that were performed using a Minolta colorimeter (Minolta Camera Ltd., Japan) in the range of 400 to $700 \mathrm{~nm}$. The $\mathrm{L}^{*}$ value measures light reflectance, and in the color scale [in a scale from 0 (black) to 100 (white)], lower L $^{\star}$ values indicate darker color and higher values indicate lighter color of the product. Positive $a^{*}$ is red and negative $a^{*}$ is green, while positive $b^{\star}$ is yellow and negative $b^{*}$ is blue. The sample was cross-sectioned at both extremities, and color measurements were done after exposing the surfaces to air for 20 minutes. The mean values of both measurements were submitted to statistical analysis. Saturation index, which indicates the color intensity, was calculated using the Equation 1 (LITTLE, 1975):

Saturation index $=\sqrt{\left(a^{\left.*^{2}+b^{*}\right)}\right.}$

Sample preparation for the assessment of nitrite and nitrate was done according to AOAC (ASSOCIATION..., 1995) and determined using flow injection spectrophotometric analysis (FiaLab2500)

\subsection{Fatty acids}

Fatty acids were analyzed at $0,6,12,18,24$, and 30 days of ripening. The samples were prepared by the saponification and esterification method of Hartman and Lago (1973) after extraction of total lipids by Folch, Less, and Stanley (1957). Fatty acid methyl esters (FAME's) were analyzed by injecting $(1 \mu \mathrm{L})$ of sample solution into a Varian CP-3800 gas chromatography system (Walnut Creek, CA, USA Palo Alto, USA), equipped with a split/splitless injector (1:100), a CP Sil 88 capillary column (50 $\mathrm{m} \times 0.25 \mathrm{~mm}$ i.d. $\times 0.2 \mu \mathrm{m}$ film thickness), a flame ionization detector (FID), and a Varian CP 8410 auto sampler. Oven temperature was set to rise from $80{ }^{\circ} \mathrm{C}$ to $150{ }^{\circ} \mathrm{C}$ at $5{ }^{\circ} \mathrm{C} / \mathrm{min}$, then from $150{ }^{\circ} \mathrm{C}$ to $220^{\circ} \mathrm{C}$ at $2{ }^{\circ} \mathrm{C} / \mathrm{min}$, and held at $220^{\circ} \mathrm{C}$ for 6 minutes. The injector and detector temperatures were fixed at $240{ }^{\circ} \mathrm{C}$ and $280^{\circ} \mathrm{C}$, respectively. Nitrogen was used as carrier gas at $1 \mathrm{~mL} / \mathrm{min}$. FAME peaks were identified by comparison of samples' retention times with authentic standards (Sigma Chemical Co., St. Louis, MO, USA). Peak area normalization method was used for quantification.

\subsection{Statistical analysis}

The data were analyzed using the MIXED procedure of SAS for repeated measures (STATISTICAL..., 2001) considering the effect of treatment and block (batch) as the main plot, ripening time as the secondary plot, and the interaction between treatment and ripening time as sources of variation. Sixteen matrices of variance and covariance were evaluated, and the matrix that best fit the data was identified considering the Akaike's Information Criterion (AIC), according to XAVIER (2000). The restricted maximum- likelihood estimation method 
was used. Treatment mean values were compared by Tukey's test $(\mathrm{P}<0.05)$.

\section{Results and discussion}

\subsection{Microbiological analyses}

All analyzed samples of salami met the microbiological standards set by the Brazilian health legislation for ripened meat products (Table 2; BRASIL, 2001). No potential risk was verified regarding the presence of spoilage, pathogenic, and/or toxigenic microorganisms. These results indicate a reduced contamination by undesirable microorganisms in meat products with good conditions of hygiene and good manufacturing practices.

The evolution of homofermentative lactic acid bacterial population found in the samples of salami during fermentation and ripening demonstrates that the population of these organisms evolved on average two log cycles during the first twelve days of ripening in all treatments. Regarding the population of Gram-positive and catalase-positive, it was observed that the microbial population remained constant up to the twelfth day in all treatments. These results showed that the starter culture added to the product was not inhibited by intrinsic factors of the respective treatments. This result is

Table 2. Estimation of microbial population in salami according to treatment and ripening time.

\begin{tabular}{|c|c|c|c|c|c|}
\hline \multirow{2}{*}{ Microorganism } & \multirow{2}{*}{$\begin{array}{l}\text { Ripening time } \\
\text { (days) }\end{array}$} & \multicolumn{3}{|c|}{ Treatment } & \multirow{2}{*}{$\begin{array}{c}\text { Pr }>\mathrm{F} \\
\text { Treatment }\end{array}$} \\
\hline & & Control & Rosemary & Rosemary + celery & \\
\hline \multirow[t]{4}{*}{ Lactic acid bacteria (Log CFU.g ${ }^{-1}$ ) } & 0 & 5.98 & 5.93 & 6.23 & 0.63 \\
\hline & 6 & 7.78 & 7.93 & 8.19 & 0.45 \\
\hline & 12 & 7.47 & 7.95 & 8.19 & 0.10 \\
\hline & 30 & 6.72 & 7.08 & 7.07 & 0.46 \\
\hline \multirow{4}{*}{ Gram-positive, catalase-positive cocci $\left(\log \mathrm{CFU} \cdot \mathrm{g}^{-1}\right)$} & 0 & 5.74 & 5.52 & 5.60 & 0.32 \\
\hline & 6 & 5.24 & 5.38 & 5.55 & 0.52 \\
\hline & 12 & 5.12 & 5.33 & 4.87 & 0.24 \\
\hline & 30 & $5.06^{\mathrm{a}}$ & $4.89^{\mathrm{a}}$ & $4.52^{\mathrm{b}}$ & 0.01 \\
\hline \multirow[t]{4}{*}{ Total aerobic mesophilic ( $\log$ CFU.g $\left.{ }^{-1}\right)$} & 0 & 5.45 & 5.61 & 5.68 & 0.46 \\
\hline & 6 & 5.61 & 5.46 & 5.28 & 0.90 \\
\hline & 12 & 5.17 & 5.04 & 5.07 & 0.97 \\
\hline & 30 & 5.37 & 5.09 & 5.25 & 0.89 \\
\hline \multirow[t]{4}{*}{ Total coliform $\left(\mathrm{MPN}_{\mathrm{N}} \mathrm{g}^{-1}\right)$} & 0 & $<1$ & $<1$ & $<1$ & - \\
\hline & 6 & $<1$ & $<1$ & $<1$ & - \\
\hline & 12 & $<1$ & $<1$ & $<1$ & - \\
\hline & 30 & $<1$ & $<1$ & $<1$ & - \\
\hline \multirow[t]{4}{*}{ Thermotolerant coliforms (MPN.g-1) } & 0 & $<1$ & $<1$ & $<1$ & - \\
\hline & 6 & $<1$ & $<1$ & $<1$ & - \\
\hline & 12 & $<1$ & $<1$ & $<1$ & - \\
\hline & 30 & $<1$ & $<1$ & $<1$ & - \\
\hline \multirow[t]{4}{*}{ Staphylococci coagulase - positive (Log CFU.g ${ }^{-1}$ ) } & 0 & $<1$ & $<1$ & $<1$ & - \\
\hline & 6 & $<1$ & $<1$ & $<1$ & - \\
\hline & 12 & $<1$ & $<1$ & $<1$ & - \\
\hline & 30 & $<1$ & $<1$ & $<1$ & - \\
\hline \multirow[t]{4}{*}{ Salmonella spp. } & 0 & Absent & Absent & Absent & - \\
\hline & 6 & Absent & Absent & Absent & - \\
\hline & 12 & Absent & Absent & Absent & - \\
\hline & 30 & Absent & Absent & Absent & - \\
\hline \multirow[t]{4}{*}{ Listeria spp. } & 0 & Absent & Absent & Absent & - \\
\hline & 6 & Absent & Absent & Absent & - \\
\hline & 12 & Absent & Absent & Absent & - \\
\hline & 30 & Absent & Absent & Absent & - \\
\hline
\end{tabular}

a,b Means followed by different letters on the row are significantly different $(\mathrm{p}<0.05)$ by Tukey's test. 
important because starter cultures can provide microbiological, physicochemical, and sensory characteristics desired in meat products (RANTSIOU et al. 2005; LEROY; VERLUYTEN; VUYST, 2006; FIORENTINI, 2008; SAWITZKI et al., 2008).

\subsection{Physicochemical and color analyses}

Water activity and $\mathrm{Na}$ concentration were not affected by the treatments $(\mathrm{p}>0.05)$, but water activity decreased $(\mathrm{p}<0.01)$ and $\mathrm{Na}$ concentration increased $(\mathrm{p}<0.01)$ over ripening time (Table 3 ). Water activity values remained below 0.90 starting at day zero and dropped sharply within the first 12 days of ripening, which means they fell below the standards set by legislation for Milano or Italian type salami (BRASIL, 2000). The water activity of salami in the present study was within safe limits to prevent the development of pathogenic microorganisms. Values of water activity in the present study are lower than those reported by Cichoski, Zis and Franceschetto (2009) in Italian type salami produced with similar content of sodium chloride.

It was observed a consistent effect of treatments on the $\mathrm{pH}$ over ripening time. In the Control and Rosemary treatments, the $\mathrm{pH}$ decreased $(\mathrm{p}<0.01)$ up to day 12 , and after that it remained almost constant. In the Rosemary + celery treatment, the $\mathrm{pH}$ remarkably decreased $(\mathrm{p}<0.01)$ by day six, remaining stable after that. Consequently, from day six of ripening, salami containing rosemary + celery showed lower $\mathrm{pH}(\mathrm{p}<0.05)$ than that of the other treatments.

For all treatments, there was a substantial drop in $\mathrm{pH}$ on the first six days of ripening compared to the $\mathrm{pH}$ values in the rest of ripening period. The initial rapid reduction in $\mathrm{pH}$ can be assigned to the production of lactic acid by Lactobacillus plantarum (FIORENTINI et al., 2001) present in the starter culture added in all treatments. Rosemary extract did not cause $\mathrm{pH}$ changes during the ripening period, but celery-based products accentuated the initial $\mathrm{pH}$ decrease maintaining the values lower than those of the other two treatments up to the end of ripening. Although the antimicrobial effect of rosemary has been proven in vitro and when applied to products (RIZNAR et al. 2006; KLANCNIK; GUZEJ; KOLAR, 2009; SHAN et al., 2009), this effect seems not to have occurred on the bacteria from the starter culture in the present study. The lower $\mathrm{pH}$ values observed in the salami containing rosemary + celery can be the result of various factors such as the presence of evaporated sugar cane juice in Veg 503, which supplied an additional source of sucrose to L. plantarum for lactic acid production, and/or a possible stimulating effect of celery on the activity of these microorganisms. The Control and Rosemary treatments had final $\mathrm{pH}$ close to that expected for Italian type salami produced in Brazil, from 5.2 to 5.4, while in the Rosemary + Celery treatment, the $\mathrm{pH}$ was lower than expected (TERRA, 2006).

Table 3. Mean values and standard errors obtained for physicochemical characteristics of salami according to treatment and ripening time.

\begin{tabular}{|c|c|c|c|c|c|}
\hline \multirow{2}{*}{$\begin{array}{c}\text { Dependent } \\
\text { variables }^{\mathrm{a}}\end{array}$} & \multirow{2}{*}{$\begin{array}{c}\text { Ripening time } \\
\text { (days) }\end{array}$} & \multicolumn{3}{|c|}{ Treatment } & \multirow{2}{*}{$\begin{array}{c}\text { Pr }>\text { F } \\
\text { Treatment }\end{array}$} \\
\hline & & Control & Rosemary & Rosemary + Celery & \\
\hline \multirow{4}{*}{ Water activity } & 0 & $0.833 \pm 0.010^{\mathrm{A}}$ & $0.840 \pm 0.014^{\mathrm{A}}$ & $0.837 \pm 0.021^{\mathrm{A}}$ & 0.95 \\
\hline & 6 & $0.772 \pm 0.008^{\mathrm{B}}$ & $0.748 \pm 0.010^{\mathrm{B}}$ & $0.784 \pm 0.004^{\mathrm{B}}$ & 0.21 \\
\hline & 12 & $0.715 \pm 0.005^{\mathrm{C}}$ & $0.723 \pm 0.011^{\mathrm{B}}$ & $0.728 \pm 0.014^{\mathrm{C}}$ & 0.55 \\
\hline & 30 & $0.672 \pm 0.013^{C}$ & $0.588 \pm 0.029^{C}$ & $0.621 \pm 0.032^{\mathrm{D}}$ & 0.12 \\
\hline $\operatorname{Pr}>$ F Ripening time & & 0.001 & 0.001 & 0.001 & \\
\hline \multirow{2}{*}{$\mathrm{Na}, \mathrm{mg} \cdot \mathrm{kg}^{-1}$} & 12 & $14006 \pm 450^{\mathrm{B}}$ & $12535 \pm 1154^{\mathrm{B}}$ & $13540 \pm 570^{\mathrm{B}}$ & 0.12 \\
\hline & 30 & $17948 \pm 451^{\mathrm{A}}$ & $17166 \pm 889^{\mathrm{A}}$ & $16702 \pm 636^{A}$ & 0.20 \\
\hline \multirow[t]{3}{*}{$\operatorname{Pr}>$ F Ripening time } & & 0.001 & 0.001 & 0.001 & \\
\hline & 0 & $5.84 \pm 0.05^{\mathrm{A}}$ & $5.83 \pm 0.06^{\mathrm{A}}$ & $5.82 \pm 0.08^{\mathrm{A}}$ & 0.92 \\
\hline & 6 & $5.23 \pm 0.09^{\mathrm{Ba}}$ & $5.20 \pm 0.12^{\mathrm{Ba}}$ & $4.95 \pm 0.12^{\mathrm{Bb}}$ & 0.001 \\
\hline \multirow{4}{*}{$\mathrm{pH}$} & 12 & $5.09 \pm 0.17^{\mathrm{Ca}}$ & $5.02 \pm 0.161^{\mathrm{Ca}}$ & $4.89 \pm 0.14^{\mathrm{Bb}}$ & 0.01 \\
\hline & 18 & $5.21 \pm 0.08^{\mathrm{BCa}}$ & $5.21 \pm 0.12^{\mathrm{BCa}}$ & $4.98 \pm 0.09^{\mathrm{Bb}}$ & 0.02 \\
\hline & 24 & $5.18 \pm 0.08^{\mathrm{BCa}}$ & $5.14 \pm 0.10^{\mathrm{BCa}}$ & $4.87 \pm 0.08^{\mathrm{Bb}}$ & 0.001 \\
\hline & 30 & $5.18 \pm 0.08^{\mathrm{BCa}}$ & $5.15 \pm 0.12^{\mathrm{BCa}}$ & $4.92 \pm 0.08^{\mathrm{Bb}}$ & 0.01 \\
\hline \multirow[t]{2}{*}{$\operatorname{Pr}>$ F Ripening time } & & 0.001 & 0.001 & 0.001 & \\
\hline & 0 & $14.80 \pm 3.59^{\mathrm{A}}$ & $9.56 \pm 1.16$ & $6.97 \pm 1.02$ & 0.10 \\
\hline \multirow{3}{*}{$\mathrm{NO}_{2}, \mathrm{mg} \cdot \mathrm{kg}^{-1}$} & 6 & $2.20 \pm 0.52^{\mathrm{B}}$ & $3.98 \pm 1.10$ & $3.51 \pm 1.19$ & 0.67 \\
\hline & 12 & $1.86 \pm 0.13^{\mathrm{B}}$ & $3.65 \pm 0.92$ & $3.47 \pm 0.87$ & 0.12 \\
\hline & 30 & $2.94 \pm 0.83^{\mathrm{bB}}$ & $3.79 \pm 1.06^{\mathrm{a}}$ & $3.64 \pm 0.95^{\mathrm{a}}$ & 0.01 \\
\hline \multirow[t]{2}{*}{$\operatorname{Pr}>$ F Ripening time } & & 0.001 & 0.10 & 0.46 & \\
\hline & 0 & $117.58 \pm 35.5$ & $82.64 \pm 32.80$ & $100.73 \pm 31.00$ & 0.09 \\
\hline \multirow{3}{*}{$\mathrm{NO}_{3}, \mathrm{mg} \cdot \mathrm{kg}^{-1}$} & 6 & $101.11 \pm 10.20$ & $81.10 \pm 9.57$ & $86.80 \pm 15.90$ & 0.93 \\
\hline & 12 & $108.45 \pm 14.00$ & $72.34 \pm 11.30$ & $86.47 \pm 12.90$ & 0.72 \\
\hline & 30 & $117.98 \pm 17.10$ & $92.94 \pm 19.10$ & $106.38 \pm 16.20$ & 0.87 \\
\hline Pr $>$ F Ripening time & & 0.71 & 0.11 & 0.16 & \\
\hline
\end{tabular}

${ }_{\text {a,b,c,d }}$ Means followed by different lower case on the row, and different capital letters in columns are significantly different $(\mathrm{p}<0.05)$ by Tukey's test. 
The $\mathrm{NO}_{2}$ content decreased with ripening time, but only in the Control treatment the differences were statistically significant $(\mathrm{p}<0.001)$ (Table 3). The Control treatment had lower $(\mathrm{p}<0.01)$ $\mathrm{NO}_{2}$ than the other treatments at day 30 ; however, this difference is of minor importance given the low magnitude of the values. Residual $\mathrm{NO}_{3}$ remained constant during ripening and was not affected by the treatments $(\mathrm{p}>0.05)$. The products derived from celery used in this study as sources of $\mathrm{NO}_{3}$ and $\mathrm{NO}_{2}$ proved to be effective, considering that residual values of $\mathrm{NO}_{3}$ and $\mathrm{NO}_{2}$ in salami were similar to the values observed in the salami added with curing salt.

Very low values of $\mathrm{NO}_{2}$ were obtained starting at day zero in all treatments and are considerably lower than the residual levels found in commercial products (SOUZA; FALEIROS; SOUZA, 1990; MELO FILHO; BISCONTINI; ANDRADE, 2004). The storage of samples and smoking process may have sped up the conversion of $\mathrm{NO}_{2}$ to $\mathrm{NO}$ and to nitrosyl myoglobin, a possible explanation for the low values found.

The results are consistent with reports of Sindelar et al. (2007b), who observed constant values of $\mathrm{NO}_{3}$ during the ripening period of cooked sausages to which only $\mathrm{NO}_{2}$ was added. Sindelar et al. (2007a) observed reduced levels of $\mathrm{NO}_{3}$ in cooked hams that were not subjected to incubation, but not in those that were incubated.

The reduction of $\mathrm{NO}_{3}$ to $\mathrm{NO}_{2}$ is accelerated by the presence of nitrate-reducing bacteria such as S. xylosus (PINTO; PONSANO; HEINEMANN, 2001) present in the starter culture used in the present study. However, this process did not take place satisfactorily. High levels of $\mathrm{NO}_{3}$ and low levels of $\mathrm{NO}_{2}$ also indicate a re-conversion of $\mathrm{NO}_{2}$ to $\mathrm{NO}_{3}$, which may be related to the preservation of samples by chilling until lyophilization and analysis. Moreover, the reduction of $\mathrm{NO}_{2}$ to $\mathrm{NO}$ is sped up by $\mathrm{NaCl}$ (FOX JUNIOR, 1987) and acidifying agents such as lactic acid bacteria (KALLE, 1955 apud FOX JUNIOR, 1987), also present in the starter culture. This is another possible explanation for the low levels of $\mathrm{NO}_{2}$ observed in the present study. Other authors have found low levels of residual nitrite in salami prepared with the addition of L. plantarum (SAWITZKI et al., 2007) or S. xylosus (FIORENTINI, 2008) as starter cultures.

When the values of $\mathrm{NO}_{2}+\mathrm{NO}_{3}$ observed at the thirtieth day of ripening are converted to the same dry matter basis found at day zero (33\% dry matter at day zero and $66 \%$ at day 30 ), it was observed a reduction of approximately $60 \%$ of the initial concentration of $\mathrm{NO}_{3}+\mathrm{NO}_{2}$ in the Control treatment, $35 \%$ in the Rosemary treatment, and $27 \%$ in the Rosemary + celery treatment. This indicates that the extracts may have somehow interfered with the transformation of $\mathrm{NO}_{2}$ and $\mathrm{NO}_{3}$ to other chemical forms.

The levels of $\mathrm{NO}_{2}$ and $\mathrm{NO}_{3}$ added to salami in the present study were relatively low considering the levels allowed by Brazilian legislation, which sets no minimum or maximum threshold of $\mathrm{NO}_{2}$ and $\mathrm{NO}_{3}$ in food products, but it does the maximum residual $\mathrm{NO}_{2}$ and $\mathrm{NO}_{3}$ (BRASIL, 1998), which are quite high compared with other countries' legislation.

Regarding the color, at the $12^{\text {th }}$ day, Control treatment salami had lower $(\mathrm{p}<0.001) \mathrm{L}^{*}$ values indicating darker color (Table 4). At later ripening times, there was no difference between the treatments. $L^{*}$ values decreased from day 12 to day 18 in the Rosemary and Rosemary + celery treatments

Table 4. Mean values and standard errors obtained for color evaluation in salami according to treatment and ripening time.

\begin{tabular}{|c|c|c|c|c|c|}
\hline \multirow{2}{*}{$\begin{array}{c}\text { Dependent } \\
\text { variables }\end{array}$} & \multirow{2}{*}{$\begin{array}{c}\text { Ripening time } \\
\text { (days) }\end{array}$} & \multicolumn{3}{|c|}{ Treatment } & \multirow{2}{*}{$\begin{array}{c}\text { Pr }>\mathrm{F} \\
\text { treatment }\end{array}$} \\
\hline & & Control & Rosemary & Rosemary + Celery & \\
\hline \multirow[t]{4}{*}{$\mathrm{L}^{*}$} & 12 & $46.70 \pm 2.04^{b}$ & $51.31 \pm 2.04^{\mathrm{Aa}}$ & $53.50 \pm 1.67^{\mathrm{Aa}}$ & 0.001 \\
\hline & 18 & $46.24 \pm 2.36$ & $49.05 \pm 2.72^{\mathrm{AB}}$ & $48.80 \pm 1.72^{\mathrm{B}}$ & 0.06 \\
\hline & 24 & $46.91 \pm 2.73$ & $48.99 \pm 2.70^{\mathrm{AB}}$ & $48.56 \pm 2.10^{\mathrm{B}}$ & 0.18 \\
\hline & 30 & $47.61 \pm 1.29$ & $47.84 \pm 2.00^{\mathrm{B}}$ & $49.18 \pm 2.20^{\mathrm{AB}}$ & 0.35 \\
\hline $\operatorname{Pr}>$ F Ripening time & & 0.46 & 0.05 & 0.001 & \\
\hline \multirow[t]{4}{*}{$a^{*}$} & 12 & $13.35 \pm 0.59^{\mathrm{B}}$ & $13.50 \pm 0.97$ & $13.30 \pm 0.64$ & 0.94 \\
\hline & 18 & $14.62 \pm 0.12^{\mathrm{A}}$ & $14.60 \pm 0.49$ & $14.40 \pm 0.23$ & 0.92 \\
\hline & 24 & $15.47 \pm 0.42^{\mathrm{AB}}$ & $16.08 \pm 0.86$ & $14.78 \pm 0.80$ & 0.12 \\
\hline & 30 & $16.33 \pm 0.62^{\mathrm{A}}$ & $15.13 \pm 0.63$ & $14.97 \pm 0.42$ & 0.07 \\
\hline $\operatorname{Pr}>$ F Ripening time & & 0.05 & 0.08 & 0.34 & \\
\hline \multirow[t]{4}{*}{$b^{*}$} & 12 & $3.09 \pm 0.62^{\mathrm{Bb}}$ & $5.65 \pm 0.85^{\mathrm{a}}$ & $6.51 \pm 0.69^{\mathrm{Aa}}$ & 0.001 \\
\hline & 18 & $2.73 \pm 0.47^{\mathrm{Bb}}$ & $5.46 \pm 0.66^{\mathrm{a}}$ & $5.20 \pm 0.63^{\mathrm{BCa}}$ & 0.001 \\
\hline & 24 & $3.97 \pm 0.83^{\mathrm{A}}$ & $5.42 \pm 1.08$ & $4.93 \pm 1.21^{\mathrm{C}}$ & 0.78 \\
\hline & 30 & $4.43 \pm 1.47^{\mathrm{Ab}}$ & $4.11 \pm 1.63^{\mathrm{b}}$ & $5.57 \pm 1.78^{\mathrm{ABCa}}$ & 0.001 \\
\hline $\operatorname{Pr}>$ F Ripening time & & 0.001 & 0.62 & 0.001 & \\
\hline \multirow[t]{4}{*}{ Color saturation } & 12 & $13.73 \pm 0.59^{\mathrm{C}}$ & $14.68 \pm 1.14$ & $14.84 \pm 0.79$ & 0.16 \\
\hline & 18 & $14.89 \pm 0.17^{\mathrm{BC}}$ & $15.64 \pm 0.37$ & $15.34 \pm 0.31$ & 0.58 \\
\hline & 24 & $16.04 \pm 0.24^{\mathrm{ABb}}$ & $17.08 \pm 0.53^{\mathrm{a}}$ & $15.74 \pm 0.50^{\mathrm{b}}$ & 0.04 \\
\hline & 30 & $17.08 \pm 0.67^{\mathrm{A}}$ & $15.86 \pm 0.48$ & $16.18 \pm 0.31$ & 0.15 \\
\hline $\operatorname{Pr}>$ F Ripening time & & 0.01 & 0.06 & 0.73 & \\
\hline
\end{tabular}

${ }_{\mathrm{a}, \mathrm{b}, \mathrm{c}}$ Means followed by different lower case on the row, and different capital letters in columns are significantly different $(\mathrm{p}<0.05)$ by Tukey's test. 
Table 5. Mean values and standard errors obtained for quantification of fatty acids in salami according to treatment and ripening time.

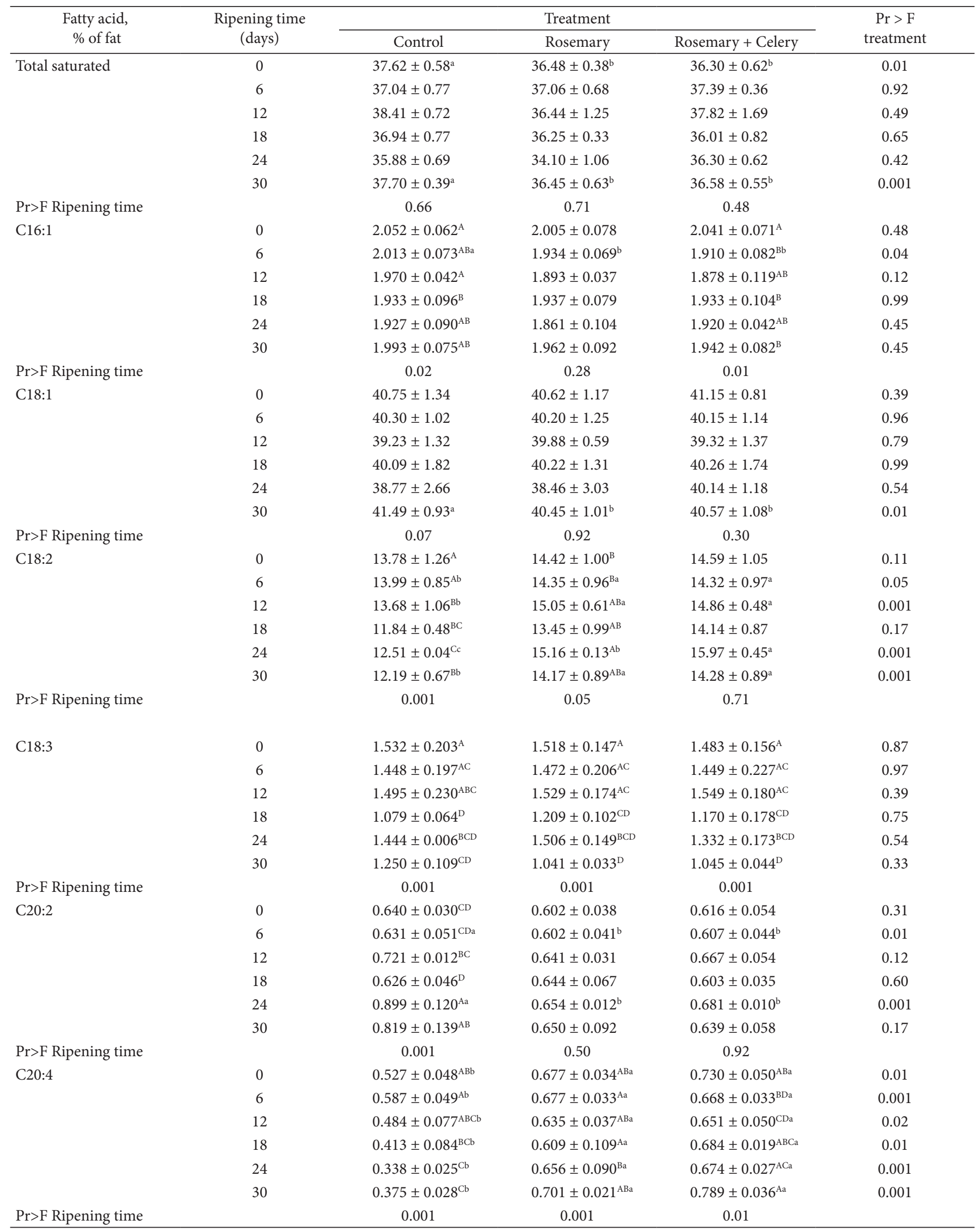

a,b,c, Means followed by different lower case on the row, and different capital letters in columns are significantly different $(\mathrm{p}<0.05)$ by Tukey's test. 
Table 5. Continued...

\begin{tabular}{|c|c|c|c|c|c|}
\hline \multirow{2}{*}{$\begin{array}{c}\text { Fatty acid, } \\
\% \text { of fat }\end{array}$} & \multirow{2}{*}{$\begin{array}{l}\text { Ripening time } \\
\text { (days) }\end{array}$} & \multicolumn{3}{|c|}{ Treatment } & \multirow{2}{*}{$\begin{array}{c}\text { Pr }>\mathrm{F} \\
\text { treatment }\end{array}$} \\
\hline & & Control & Rosemary & Rosemary + Celery & \\
\hline \multirow[t]{5}{*}{ Total omega-9 } & 0 & $42.80 \pm 1.38^{\mathrm{AB}}$ & $42.63 \pm 1.24$ & $43.19 \pm 0.85$ & 0.74 \\
\hline & 6 & $42.31 \pm 1.06^{\mathrm{B}}$ & $42.13 \pm 1.30$ & $42.06 \pm 1.21$ & 0.94 \\
\hline & 12 & $41.21 \pm 1.30^{\mathrm{AB}}$ & $41.78 \pm 0.55$ & $41.20 \pm 1.45$ & 0.67 \\
\hline & 18 & $42.02 \pm 1.90^{\mathrm{AB}}$ & $42.16 \pm 1.37$ & $42.19 \pm 1.82$ & 0.97 \\
\hline & 24 & $40.70 \pm 2.75^{\mathrm{AB}}$ & $40.32 \pm 3.13$ & $42.06 \pm 1.22$ & 0.18 \\
\hline Pr $>$ F Ripening time & & 0.02 & 0.23 & 0.70 & \\
\hline \multirow[t]{4}{*}{ Total omega- 6} & 0 & $14.42 \pm 1.29^{\mathrm{A}}$ & $15.02 \pm 1.04^{\mathrm{B}}$ & $15.20 \pm 1.10$ & 0.13 \\
\hline & 6 & $14.62 \pm 0.90^{\mathrm{A}}$ & $14.96 \pm 1.00^{\mathrm{B}}$ & $14.92 \pm 1.01$ & 0.08 \\
\hline & 12 & $14.40 \pm 1.05^{\mathrm{Bb}}$ & $15.69 \pm 0.64^{\mathrm{ABa}}$ & $15.53 \pm 0.52^{\mathrm{a}}$ & 0.001 \\
\hline & 18 & $12.46 \pm 0.48^{\mathrm{BD}}$ & $14.10 \pm 1.00^{\mathrm{AB}}$ & $14.74 \pm 0.90$ & 0.17 \\
\hline
\end{tabular}

a,b,c,d Means followed by different lower case on the row, and different capital letters in columns are significantly different $(\mathrm{p}<0.05)$ by Tukey's test.

and remained stable from that point on. The extracts had no significant effect $(p<0.05)$ on the $a^{*}$ values (redness) of the products. With regard to the ripening time, in the Control treatment, redness was higher $(\mathrm{p}<0.05)$ at days 18 and 30 of ripening than at the other days.

Salami of the Rosemary and Rosemary + celery treatments had higher $(\mathrm{p}<0.001) \mathrm{b}^{*}$ values at the $12^{\text {th }}$ and $18^{\text {th }}$ days of ripening. At the $24^{\text {th }}$ day, no difference was detected between the treatments, and at the $30^{\text {th }}$ day, Rosemary + celery treatment salami showed higher $(p<0.001) b^{*}$ values than those of the other treatments.

It was observed an increase $(\mathrm{p}<0.01)$ in the color saturation index during the ripening period in the Control treatment, but the other treatments showed no influence of ripening time. At the $24^{\text {th }}$ day of ripening, the color saturation index was higher $(p<0.04)$ in the salami of the Rosemary treatment compared with the other treatments. Higher saturation index, as well as, higher $\mathrm{a}^{\star}$ values and lower $\mathrm{b}^{\star}$ values indicate a more favorable color, or less discoloration (fading) of the product. The highest $\mathrm{L}^{*}$ values observed in the treatments containing smaller amounts of $\mathrm{NO}_{3} / \mathrm{NO}_{2}$ (Rosemary and Rosemary + Celery treatments) indicate lighter color. This difference disappeared up to day 18 of ripening suggesting that the salami with lower content of $\mathrm{NO}_{3} / \mathrm{NO}_{2}$ took longer to develop the typical color of the product, which results from the synthesis of nitrosyl myoglobin (FOX JUNIOR, 1987). These results are in agreement with those found by Sindelar et al. (2007a, b), who observed no changes in cured color in sausages and ham produced with addition of vegetable juice powder and without curing salt.

Since the treatments showed similar color saturation index for most of the periods evaluated, as well as similar $\mathrm{a}^{*}$ values at all ripening times, despite the higher $b^{*}$ values, it can be considered that the products containing rosemary and rosemary + celery developed adequate color and resistance to discoloration, especially from day 18 , when $\mathrm{L}^{\star}$ values (reflectance) became similar between the treatments. This is important from the point of view of consumer preferences since color is among the most appealing characteristics affecting the decision-making for buying meat (BREWER, 1998). Presence of antioxidants in the tissues can reduce the oxidation of muscle pigments, thus improving color during extended storage (ZANARDI et al., 1998).

\subsection{Fatty acids}

Fatty acids (C16:1, C18:1, and C20:2) and the sum of saturated fatty acids showed differences $(p<0.05)$ between the treatments at some ripening periods (Table 5 ). The sum of omega-9 fatty acids (C16:1 and C18:1) was not different $(p>0.05)$ between the treatments at any ripening time. On the other hand, C18:2 was lower $(\mathrm{p}<0.05)$ in the Control treatment than in the other two treatments from the $6^{\text {th }}$ day and nearly in all ripening times; the same behavior was found for the sum of omega- 6 fatty acids (C18:2 and C20:2; $<<0.01)$ from day 12 . The content of C20:4 fatty acid was lower $(\mathrm{p}<0.05)$ in the Control treatment at all ripening times.

Higher levels of C20:4 from day zero in the treatments with rosemary extract could be the result of the presence of this fatty acid in the oil extract. The reduction of the content of C18:2, C20:4, and the sum of omega- 6 , throughout the ripening period in the Control treatment may have been caused by the degradation of fatty acids (Beta oxidation). In the treatments containing rosemary extract, the levels of these fatty acids did not change during the ripening period suggesting a protective effect of this product against polyunsaturated fatty acid oxidation, greater than that provided by $\mathrm{NO}_{2}$. 
These results are consistent with those of previous studies, in which the antioxidant effect of rosemary in foodstuffs has been demonstrated for chicken sausages (RIZNAR et al., 2006) and raw pork (SHAN et al., 2009). Basmacioglu, Tokusoglu and Ergul (2004) reported that rosemary oil can prevent lipid oxidation in chicken meat through their inclusion in the diet of these animals, even when enriched with omega- 3 fatty acids.

Volatile compounds resultant from lipid oxidation during processing, ripening, and cooking are important components for taste and flavor development, and, consequently, for acceptability of meat and meat products by consumers. Polyunsaturated fatty acids have low oxidative stability, which may result in the production of undesirable volatile compounds, responsible by off-flavors, thus negatively influencing flavor and taste in meat and meat products (DAZA et al., 2005; MUSELLA et al., 2009). The compounds resulting from fat deterioration are also a potential risk to human health, with the production of toxic or toxigenic substances (MORRISSEY et al., 1998). Therefore, the importance of the protective effects of vegetable extracts against fatty acids oxidation is worth noting.

\section{Conclusions}

The production of salami containing rosemary extract and reduced levels of added nitrite and nitrate resulted in a product with physical and chemical characteristics and residual levels of nitrite and nitrate similar to those of conventional salami.

The addition of rosemary extract and celery powder in the formulation did not inhibit the development of the starter culture added to the salami confirming the influence of the cultures on important properties of the final product.

There is evidence that the rosemary extract reduced the oxidation of some types of unsaturated fatty acids during ripening. At longer ripening periods, the salamis with rosemary extract may have advantages in terms of fat oxidation, but this finding needs to be confirmed by further studies with direct evaluation of the oxidation products.

Reduced addition of $\mathrm{NO}_{3}$ and $\mathrm{NO}_{2}$ to the salami did not affect the levels of residual nitrate and nitrite, but it influenced the color of the product during the early stages of ripening. This difference gradually disappeared over the ripening period. Therefore, with longer ripening periods, products tend to be similar in quality.

The specific products used in the present study originated from dehydrated celery proved to be effective sources of $\mathrm{NO}_{3}$ and $\mathrm{NO}_{2}$ for color development and for maintenance of low residual levels of $\mathrm{NO}_{3}$ and $\mathrm{NO}_{2}$ compared with the same added levels of $\mathrm{NO}_{3}+\mathrm{NO}_{2}$ from curing salt. However, the excessive acidification of the product indicates the need to better evaluate its use in fermented salami.

\section{Acknowledgements}

The authors thank to the Federal Institute of Technological Education of Concórdia, Santa Catarina State, for providing the facilities to prepare the salami for this project.

\section{References}

AMERICAN PUBLIC HEALTH ASSOCIATION - APHA. Compendium of methods for microbiological examination of food. 3rd ed. Washington: APHA, 1992.

ASOLINI, F. C.; TEDESCO, A. M.; CARPES, S. T. Antioxidant and antibacterial activities of phenolic compounds from extracts of plants used as tea. Brazilian Journal of Food and Technology, v. 9, n. 3, p. 209-215, 2006.

ASSOCIATION OF OFFICIAL ANALYTICAL CHEMISTS - AOAC. Official Methods of Analysis of the Association of Official Analytical Chemists. Arlington: AOAC,1995. chapt. 39, p. 13-5.

BASMACIOGLU, H.; TOKUSOGLU, O.; ERGUL, M. The effect of oregano and rosemary essential oils or alpha-tocopheryl acetate on performance and lipid oxidation of meat enriched with n-3 PUFA's in broilers. South African Journal of Animal Science, v. 34, n. 3, p. 197-210, 2004.

BRASIL. Ministério da Saúde. Secretaria de Vigilância Sanitária. Portaria $\mathrm{n}^{\circ} 1.004$, de 11 de dezembro de 1998. Regulamento Técnico: Atribuição de Função de Aditivos. Aditivos e seus Limites Máximos de uso para a Categoria 8 - Carne e Produtos Cárneos. Diário Oficial da República Federativa do Brasil, Brasília, DF, 14 dez. 1998. Seção 1, n. 239, p. 28-32.

BRASIL. Ministério da Agricultura Pecuária e Abastecimento. Instrução Normativa $n^{\circ} 22$, de 31 de julho de 2000. Anexo V: Regulamento técnico de identidade e qualidade de salame. Diário Oficial da República Federativa do Brasil, Brasília, DF, 3 ago. 2000. Seção 1, p. 15.

BRASIL. Ministério da Saúde. Agência Nacional de Vigilância Sanitária - ANVISA. Resolução nº 12 de 02 de janeiro de 2001. Regulamento Técnico sobre padrões microbiológicos para alimentos. Diário Oficial da República Federativa do Brasil, Brasília, DF, jan. 2001. Disponível em: <http://www.anvisa.gov. br/e-legis $>$. Acesso em: 30 jun. 2010.

BREWER, M. S. Consumer Attitudes: What they say and what they do. Des Moines: National Pork Board, 1998. (Facts. Pork Quality). Disponível em: <http://www.pork.org/filelibrary/ Factsheets/PorkScience/consumerattitudes04621.pdf $>$. Acesso em: 7 maio 2012.

CICHOSKI, A. J.; ZIS, L. C.; FRANCESCHETTO, C. Características físico-químicas e microbiológicas da superfície do salame tipo italiano contendo solução de lactato de potássio. Ciência e Tecnologia de Alimentos, v. 29, n. 3, p. 546-552, 2009. http://dx.doi. org/10.1590/S0101-20612009000300015

DAZA, A. et al. Effects of feeding in free-range conditions or in confinement with different dietary MUFA/PUFA ratios and a-tocopheryl acetate, on antioxidants accumulation and oxidative stability in Iberian pigs. Meat Science, v. 69, n. 1, p. 151-163, 2005. PMid:22062651. http://dx.doi.org/10.1016/j.meatsci.2004.06.017

ESPÍNDOLA, C. E. Tecnologia e novas relações de trabalho nas agroindústrias de carne do sul do Brasil. Revista Electrónica de Geografía y Ciencias Sociales, v. 6, n. 119, 2002. Disponível em: <http://www.ub.es/geocrit/sn/sn119-85.htm>. Acesso em: 30 set. 2010.

FIORENTINI, A. M. Caracterização e propriedades tecnológicas de Staphylococcus xylosus isoladas de salames artesanais e aplicação como cultura iniciadora em salame tipo milano. 2008. Tese (Doutorado em Ciência e Tecnologia de Alimentos)-Universidade Federal de Santa Catarina, Florianópolis, 2008.

FIORENTINI, A. M. et al. Influence of bacteriocins produced by Lactobacillus plantarum BN in the shelf-life of refrigerated bovine 
meat. Brazilian Journal of Microbiology, v. 32, p. 42-46. 2001. http://dx.doi.org/10.1590/S1517-83822001000100010

FOLCH, J.; LESS, M.; STANLEY, S. A simple method for the isolation and purification of total lipids from animal tissues. The Journal of Biological Chemistry, v. 226, p. 497-509, 1957. PMid:13428781.

FOXJUNIOR, J. B. The pigments of meat. In: PRICE, J. F.; SCHWEIGERT, B. S. The Science of Meat and Meat Products. 3rd. ed. Westport: Food \& Nutrition Press, 1987. p.193-216.

HARTMAN, L.; LAGO, R. C. A. Rapid preparation of fatty acid methyl esters from lipids. Laboratory Practices, v. 22, p. 475-481, 1973. PMid:4727126.

KLANCNIK, A.; GUZEJ, B.; KOLAR, M. H. In vitro antimicrobial and antioxidant activity of commercial rosemary extract formulations. Journal of Food Protection, v. 72, n. 8, p. 1744-1752, 2009. PMid:19722413.

LEE, K. G.; SHIBAMOTO, T. Determination of antioxidant potential of volatile extracts isolated from various herbs and spices. Journal of Agricultural and Food Chemistry, v. 50, p. 4947-4952, 2002. PMid:12166987. http://dx.doi.org/10.1021/jf0255681

LEROY, F.; VERLUYTEN, J.; VUYST, L. D. Functional meat starter culturesfor improved sausage fermentation. International Journal of Food Microbiology, v. 106, p. 270-285, 2006. PMid:16213053. http://dx.doi.org/10.1016/j.ijfoodmicro.2005.06.027

LITTLE, A. C. Off on a tangent. Journal of Food Science, v. 40, p. 410-411, 1975. http://dx.doi.org/10.1111/j.1365-2621.1975. tb02213.x

LOPEZ-BOTE, C. J. et al. Effect of dietary administration of oil extracts from rosemary and sage on lipid oxidation in broiler meat. British Poultry Science, v. 39, p. 235-240, 1998. PMid:9649877. http:// dx.doi.org/10.1080/00071669889187

MELO FILHO, A. B.; BISCONTINI, T. M. B.; ANDRADE, S. A. C. Níveis de nitrito e nitrato em salsichas comercializadas na região metropolitana de Recife. Ciência e Tecnologia de Alimentos, v. 24 , n. 3, p. $390-392,2004$. http://dx.doi.org/10.1590/S010120612004000300015

MORRISSEY, P. A. et al. Lipid stability in meat and meat products. Meat Science, v. 49, p. S73-S86, 1998. Suplemento 1.

MUSELLA, M. et al. Omega-3 polyunsaturated fatty acid from extruded linseed influences the fatty acid composition and sensory characteristics of dry-cured ham from heavy pigs. Journal of Animal Science, v. 87, p. 3578-3588, 2009. PMid:19648498. http:// dx.doi.org/10.2527/jas.2008-1355

PINTO, M. F.; PONSANO, E. H. G.; HEINEMANN, R. J. B. Bactérias envolvidas no processamento de produtos cárneos. Boletim Sociedade Brasileira de Ciência e Tecnologia de Alimentos, v. 35, n. 1-2, p. 109-116, 2001.

RABABAH, T. et al. Effect of electron bean irradiation and storage at $5{ }^{\circ} \mathrm{C}$ on thiobarbituric acid reactive substances and carbonyl contents in chicken breast meat infused with antioxidants and selected plant extracts. Journal of Agricultural and Food Chemistry, v. 52, p. 8236-8241, 2004. PMid:15612823. http://dx.doi. org/10.1021/jf049147q

RANTSIOU, K. et al. Ecology and characterization by molecular methods of Staphylococcus species isolated from fresh sausages. International Journal of Food Microbiology, v. 97, p. 277-284, 2005. PMid:15582738. http://dx.doi.org/10.1016/j. ijfoodmicro.2004.02.018

RIZNAR, K. et al. Antioxidant and antimicrobial activity of rosemary extract in chicken frankfurters. Journal of Food Science, v. 71, n. 7, p. c425-c429, 2006. http://dx.doi.org/10.1111/j.17503841.2006.00130.x

SANTAMARIA, P. Nitrate in vegetables: toxicity, content, intake and EC regulation. Journal of the Science of Food and Agriculture, v. 86, p. 10-17, 2006. http://dx.doi.org/10.1002/jsfa.2351

SAWITZKI, M. C. et al. Phenotypic characterization and speciesspecific pcr of promising starter culture strains of lactobacillus plantarum isolated from naturally fermented sausages. Brazilian Journal of Microbiology, v. 38, p. 547-552, 2007. http://dx.doi. org/10.1590/S1517-83822007000300031

SAWITZKI, M. C. et al. Lactobacillus plantarum AJ2 isolated from naturally fermented sausage and its effects on the technological properties of Milano-type salami. Ciência e Tecnologia de Alimentos, v. 28, n. 3, p. 709-717, 2008.

SHAN, B. et al. Antibacterial and antioxidant effects of five spice and herb extracts as natural preservatives of raw pork. Journal of the Science Food and Agriculture, v. 89, p. 1879-1885, 2009. http:// dx.doi.org/10.1002/jsfa.3667

SINDELAR, J. J. et al. Effects of vegetable juice powder concentration and storage time on some chemical and sensory quality attributes of uncured, emulsified cooked sausages. Journal of Food Science, v. 72, n. 5, p. S324-S332, 2007a. PMid:17995750. http://dx.doi. org/10.1111/j.1750-3841.2007.00369.x

SINDELAR, J. J. et al. Effects of varying levels of vegetable juice powder and incubation time on color, residual nitrate and nitrite, pigment, $\mathrm{pH}$, and trained sensory attributes of readyto-eat uncured ham. Journal of Food Science, v. 72, n. 6, p. S388-S395, 2007b. PMid:17995695. http://dx.doi.org/10.1111/ j.1750-3841.2007.00404.X

SOUZA, P. A.; FALEIROS, R. R. S.; SOUZA, H. B. A. Dosagem de nitrito e nitrato em produtos embutidos de carne. Alimentação e Nutrição, v. 2, p. 27-34, 1990.

STATISTICAL ANALYSIS SYSTEM - SAS. SAS user's guide: statistics. Version 8. Carry, 2001. 155 p.

TERRA, N. N. Particularidades na fabricação de salame. In: SHIMOKOMAKI, M. et al. Atualidades em Ciência e Tecnologia de Carnes. São Paulo: Varela, 2006. 236 p.

XAVIER, L. H. Modelos univariado e multivariado para análise de medidas repetidas e verificação da acurácia do modelo univariado por meio de simulação. 2000. 91 f. Dissertação (Mestrado)-Escola Superior de Agricultura "Luiz de Queiroz", Universidade de São Paulo, Piracicaba, 2000.

YEN, G. C.; CHEN, H. Y. Antioxidant activity of various tea extracts in relation to their antimutagenicity. Journal of Agricultural and Food Chemistry, v. 43, p. 27-32, 1995. http://dx.doi.org/10.1021/ jf00049a007

ZANARDI, E. et al. Oxidative stability and dietary treatment with vitamin E, oleic acid and copper of fresh and cooked pork chops. Meat Science, v. 49, n. 3, p. 309-320, 1998. 